\title{
Trend Analysis and Purpose of Use of Some Important Plant and Animal Species of Ghandruk VDC, Nepal
}

\author{
Y.P. Adhikari* and A. Fischer \\ Geobotany, Department of Ecology and Ecosystem Management, Technische Universität München, Hans-Carl- \\ von-Carlowitz-Platz 2, D-85354 Freising, Germany \\ *E-mail: yadhikari25@gmail.com
}

Received: 07.09.2010, Accepted: 15.11.2010

\begin{abstract}
Ghandruk is one of the famous tourism VDC of Annapurna Conservation Areas (ACA). Trend analysis and propose of use of plants and animal species of Ghandruk Village Development Committee of Kaski district, western part of Nepal was carried out. A total of 54 plant species and 18 animal species with high local economic value were documented from structured questionnaire, interviews, key informants interviews, and focused group discussion with representatives and ACAP staffs. Trend analysis shows that most of the species increased during the past 20 years. All species are equally important for their purpose of uses. Michelia champaca, Schima wallichii, Castanopsis indica are very important trees for timber production. Quercus lamelossa, $Q$. semicarpifolia and Ficus roxburghii are very good fodder species. Alnus nepalensis colonizes landslides and degraded sites very successfully. Leaf extract of Ageratum conyzoides and fur of Lepus nigricollis is used to control bleeding from cuts and wounds. Medicinal plants, Terminalia bellirica, Terminalia chebula, Acorus calamus and Curcuma langa are used to control cough and bronchitis. The litter of plants is used to make compost fertilizer. Some animals were found the important medicinal purposes, some other used for control mouse populations. Some animals like Canis aureus and Martes flavigula, however, were found to be pests for domestic animals.
\end{abstract}

Key words: Medic ine, timber, fodder, resource, sustainable, Ghandruk, Nepal

\section{Introduction}

Analysis of observed temperature and precipitation records in Nepal shows that temperature in Nepal is increasing at a high rate in comparison to other mountains of the world (Shrestha et al., 1999). The warming seems to be consistent and continuous after the mid-1970s and found to be more pronounced at high altitude. Therefore, the studies of climate change are urgently needed in order to better understanding the linkage between changing climatic pattern, increasing natural hazards and its effects on livelihood. But the climatic records in Nepal are very limited. Most of the meteorological stations are located at lower elevation $(<2000 \mathrm{~m})$, therefore time series analysis of recorded climate data for the assessment of climate change at higher altitude is not possible. We need to identify alternative way to study climate. One of such alternative could be dendrochronology, and dendroclimatology.

Nepal, a small Himalayan kingdom with an area covering $147,181 \mathrm{~km}^{2}$, representing $0.03 \%$ and $0.3 \%$ of the total land of the world and of Asia, respectively, 
is endowed with rich biodiversity. Over 7,000 species of plants, 175 species of mammals and 861 species of birds are recorded in Nepal (BCDP, 1994).Vegetation is an important carrier of biodiversity (Hellier et al., 1999). In addition, forests provide a wide variety of ecological services, which should be maintained. Social sustainability requires that natural resource use meets human needs without disrupting environment and social harmony beyond capacity of social structure to tolerate such change (Wollenberg, 1995). The forest biomass (timber, wood) is an important source of fuel, fodder, or building material. The value of forest as an energy resource is very important, providing $75 \%$ of total energy needs in Nepal (MOPE, 1998).

This study examines the allocation of natural resources in Ghandruk village. Forest resource management in Ghandruk has been documented by several authors (Rayamajhi, 1994; Jones, 1996; Banskota and Sharma, 1997). Rayamajhi (1994) emphasized that the management of forest resources should lie with the people themselves since they have detailed knowledge of the local ecology and environment and know which methods are appropriate to the means, organizations, and traditions of their community. There is remarkable ethnic and biological diversity and wealth of indigenous knowledge of plants and animals with economic value (Tamang, 2003). In absence of alternative modern medicine and belief on the traditional medicine, plants will continue to be a major source of medicine in near future for the people living in the Himalayas (Shrestha and Jha, 2009).

Jones (1996) stated that community development and biodiversity conservation are complementary concepts and considered that social development without biodiversity conservation and biodiversity conservation without social development are inappropriate processes. Jackson and Ingles (1995) discussed several factors that limit Nepal's efforts to increase the welfare of rural people and manage natural resources in sustainable manner.

Ghandruk is one of villages, with social harmonies, cultural sharing and community work participating. There is an outstanding indigenous knowledge of plant and animal species with high economic value. Trend analysis and documentation of plant and animal species with their economic value is helpful to preserve the record of diversified utilization of the flora and fauna in the study area.

Ghandruk VDC lies in Kaski district $\left(28.49^{\circ} \mathrm{N}-83.84^{\circ} \mathrm{E}\right)$ of Gandaki zone, western Nepal. It is on the route to Annapurna Base Camp with 30,000 trekker visits annually (BCDP, 1994). It is situated at an elevation of $1,975 \mathrm{~m}$ asl on the west slopes of the Modi watershed. The topography is moderately steep with aspects mainly facing south. Monsoonal precipitation is relatively high with an average of $3000 \mathrm{~mm}$ annual precipitation (BCDP, 1994). Ghandruk in 2008 had a total population of 6,158 people $(2,993$ male and 3,165 female). About 1446 households exist with an average household size of 4.25 people (ACAP, 2008). The majority belongs to the Gurung people with occupational castes and Brahmins intermingled at the periphery of the main Ghandruk villages. The local economy is characterized by agriculture (maize, millet, barley, rice and wheat are the major crops, while potatoes, mustard and other vegetables are also grown) livestock farming, overseas 
employment and tourist trade. Buffaloes are kept for milk, ox are kept for ploughing, while cows are kept by few Gurungs, Brahmins and other castes. Sheep and goats are raised for wool and meat. Woollen products are essential for making Bakkhu (warm woollen cloth) which is used to keep off the rain and the mountain chill (BCDP, 1994).

\section{Materials and methods}

Based on primary and secondary data sources both quantitative and qualitative data have been collected during summer 2008. The primary data were collected during field work through household surveys, interviews of key informants, informal interviews, focused group discussions with user member and officials, and direct field observations. The secondary data were obtained from published and unpublished materials such as office records, ACAP reports, community forest administration, local government and community, journals and reports. Besides these, different accessible resource libraries (TU, TUM, ACAP Pokhara) were approached. Stratified random sampling was used to select the sample households. Household surveys were carried out using a random sample of 46 respondents, comprising 22 males and 24 females. The main respondents were heads of households. Other members of households were also requested to share knowledge and opinions. The Conservation Area Management Committee members, women, Dalit and ACAP people were called upon and made focused group discussion to express the existing situation in regards to participation, transparency, accountability and predictability of the group. The discussions were made at groups and a total of 15 participants were involved for expressing their opinions and thoughts. The collected specimens were identified with the available literature (Shrestha, 1997; Shrestha, 1998; Polunin and Stainton, 1984) and for further confirmation specimens were taken to Godawari herbarium (KATH) and Central Department of Botany. 52 important species of plants and 18 species of animals were studied.

\section{Results and discussion}

The analysis shows that only few species of the study area, important for different purposes, increased. The number of plant and animal species, which Ghandruk people use for different purposes either from traditional knowledge or modified knowledge is remarkable (Tabs. 1-2). During the survey we also noticed that not only the utilisation increased but also the conservation awareness among local people resulting from environmental education. Observations of animal track counts, pellet counts and direct observations of selected species such as barking deer (Muntiacus muntjak) and Himalayan tahr (Hemitragus jemlahicus) indicated higher abundances within ACA (Bajracharya et al., 2005). In turn people living in and around Ghandruk became aware on the importance of natural resource and the benefits of plant and animal species, which enhances them for the establishment of different user groups like Women Group. The mean density of cut tree stumps was significantly lower inside ACA, associated with a decline in use of fuel wood as an energy source over the past decade. Study survey also shows that population of most of all plant and wild animal species increased. Similar results 
Y.P. Adhikari and A. Fischer / Our Nature (2010) 8: 122 -130

Table 1. Main plant species used in Ghandruk village and status trends

\begin{tabular}{|c|c|c|c|c|}
\hline $\begin{array}{l}\text { Local } \\
\text { name }\end{array}$ & Botanical name & Propose of use & Part Used & $\begin{array}{l}\text { Status trend- } \\
\text { last } 2 \text { decades }\end{array}$ \\
\hline bhojho & Acorus calamus $\mathrm{L}$. & $\begin{array}{l}\text { Medicine for cough and } \\
\text { bronchitis }\end{array}$ & Stem & Increased \\
\hline $\begin{array}{l}\text { ghandhe } \\
\text { jhar }\end{array}$ & Ageratum conyzoides $\mathrm{L}$. & $\begin{array}{l}\text { Medicine for cuts and } \\
\text { wounds }\end{array}$ & Leaf extract & Increased \\
\hline uttis & Alnus nepalensis D.Don & Fuel, wood, timber, litter & Wood, leaf & Increased \\
\hline tite pati & Artemisia indica Willd. & $\begin{array}{l}\text { Medicine for nausea } \\
\text { problem and intestinal } \\
\text { worms, cultural value, } \\
\text { nursery seed cover, fodder } \\
\text { for goat }\end{array}$ & $\begin{array}{l}\text { Leaf, root, } \\
\text { flower, }\end{array}$ & Increased \\
\hline nigalo & Arundinaria aristata Gamble & $\begin{array}{l}\text { Vegetable, hand icraft, } \\
\text { decoration (rest., hotel, } \\
\text { house) fence }\end{array}$ & $\begin{array}{l}\text { New shoot (tusa) } \\
\text { leaf, wood }\end{array}$ & Constant \\
\hline kurilo & Asparagus racemosus Willd. & Vegetable, medicine & $\begin{array}{l}\text { Baby plants, } \\
\text { roots }\end{array}$ & Constant \\
\hline koiralo & Bauhinia variegata $\mathrm{L}$ & $\begin{array}{l}\text { Medicine for dysentery, } \\
\text { piles, diarrhoea, worms and } \\
\text { fodder }\end{array}$ & $\begin{array}{l}\text { Flower, leaf and } \\
\text { seed }\end{array}$ & Increased \\
\hline chutro & Berberis aristata DC. & $\begin{array}{l}\text { Medicine for fever,jundice } \\
\text { and fodder }\end{array}$ & $\begin{array}{l}\text { Stem, leaf and } \\
\text { fruit }\end{array}$ & Increased \\
\hline chuletro & $\begin{array}{l}\text { Brassiopsis polycantha (Wall.) } \\
\text { Banerjee }\end{array}$ & Fodder, fuel, recreation & Leaf, wood & Increased \\
\hline$\overline{\text { simal }}$ & Bombax ceiba $\mathrm{L}$ & $\begin{array}{l}\text { Gum, timber, fuel, } \\
\text { medicine for dysentery and } \\
\text { diarrhoea }\end{array}$ & $\begin{array}{l}\text { Bark, leaf, seed } \\
\text { and wood }\end{array}$ & Constant \\
\hline kalki phool & $\begin{array}{l}\text { Callistemon citrinus (Curtis) } \\
\text { Skeel }\end{array}$ & Fodder, fuel, ornamental & Leaf, wood & Increased \\
\hline gaja & Cannabis sativa $\mathrm{L}$ & Use for pain killer, smoke & Leaf, seed & Constant \\
\hline gholtapre & Centella asiatica $(\mathrm{L}) \mathrm{Urb}$ & $\begin{array}{l}\text { Medicine for skin disease } \\
\text { and digestion }\end{array}$ & Steam and leaf & Increased \\
\hline haledo & Curcuma langa $\mathrm{L}$ & $\begin{array}{l}\text { Medicine for cough and } \\
\text { bronchitis and use as } \\
\text { gradients in vegetables }\end{array}$ & $\begin{array}{l}\text { Leaf and } \\
\text { powder }\end{array}$ & Increasad \\
\hline akash beli & Cuscuta reflexa Roxb & Medicine for jundice & Tendril & Increased \\
\hline kaduz & Castanopsis indica (Roxb.) Miq. & Timber & $\begin{array}{l}\text { Leaf, wood, } \\
\text { steam }\end{array}$ & Increased \\
\hline panisaro & $\begin{array}{l}\text { Cautleya spicata (J.E. Smith) } \\
\text { Baker }\end{array}$ & $\begin{array}{l}\text { Juice, medicine, used for } \\
\text { hot }\end{array}$ & Leaf, roots & Increased \\
\hline$\overline{l a p s i}$ & $\begin{array}{l}\text { Choerospondias axillaries (Roxb.) } \\
\text { B.L. Brutt \& A.W. Hill }\end{array}$ & Wood, pickle, fuel, jam & Fruits, wood & Constant \\
\hline
\end{tabular}


Y.P. Adhikari and A. Fischer / Our Nature (2010) 8: 122 -130

\begin{tabular}{|c|c|c|c|c|}
\hline dalchini & $\begin{array}{l}\text { Cinnamomum tamala (Buch.- } \\
\text { Ham) Nees \& Eberm. }\end{array}$ & Tobacco, tea and species & $\begin{array}{l}\text { Root, wood } \\
\text { cover, leaf }\end{array}$ & Increased \\
\hline haledo & Curcuma angustisfolia Roxb. & Medicine & Roots, leaf & Increased \\
\hline panchaule & $\begin{array}{l}\text { Dactylorhiza hatagirea (D. Don) } \\
\text { Soo }\end{array}$ & $\begin{array}{l}\text { Medicine used paste on } \\
\text { burnt part of human and } \\
\text { animal }\end{array}$ & Roots, leaf & Increased \\
\hline dar & $\begin{array}{l}\text { Debregeasia salicifolia (D. Don) } \\
\text { Rendle. }\end{array}$ & $\begin{array}{l}\text { Cultural value, recreational, } \\
\text { wooden pot, fuel. Wood }\end{array}$ & Wood, leaf & Increased \\
\hline tama bans & $\begin{array}{l}\text { Dendrocalamus hamiltonii Nees } \\
\text { \& Arn.ex Munro }\end{array}$ & $\begin{array}{l}\text { Vegetable, handicraft } \\
\text { decoration, fence, fuel }\end{array}$ & $\begin{array}{l}\text { Baby bamboo, } \\
\text { leaf, wood }\end{array}$ & Increased \\
\hline dudhilo & Ficus nerifolia $\mathrm{Sm}$. & Fodder, fuel & Leaf, wood & Increased \\
\hline nimaro & Ficus roxburghii Wall. & $\begin{array}{l}\text { Fuel, fodder, cultural } \\
\text { value,fruits }\end{array}$ & $\begin{array}{l}\text { Leaf, wood, } \\
\text { fruits }\end{array}$ & Increased \\
\hline khainyu & $\begin{array}{l}\text { Ficus semicordata Buch.-Ham.ex } \\
\text { Sm. }\end{array}$ & Fodder, fuel, wood & Leaf, wood & Increased \\
\hline okhar & Juglans regia $\mathrm{L}$. & $\begin{array}{l}\text { Fruits, wood, fuel, cultural } \\
\text { value }\end{array}$ & $\begin{array}{l}\text { Fruits, leaf, } \\
\text { wood }\end{array}$ & Constant \\
\hline ashuro & Justicia adhatoda $\mathrm{L}$ & Medicine & Leaf & Increased \\
\hline siltimur & Litsea cubeba (Lour) pers. & $\begin{array}{l}\text { Medicine for cholera, also } \\
\text { use in vegitables and pickel }\end{array}$ & Seed & Constant \\
\hline angeri & Lyonia avalifolia (Wall.) Drude & $\begin{array}{l}\text { Medicine, reduce blood } \\
\text { pressure }\end{array}$ & Leaf, fruits & Increased \\
\hline mallow & Malva neglecta Wallr. & Juice, jam & Fruit & Increased \\
\hline bakaino & Melia azedarach $\mathrm{L}$ & $\begin{array}{l}\text { Medicine for fever, } \\
\text { headache, loose bowel and } \\
\text { fuel }\end{array}$ & Seed and trunk & Constant \\
\hline champ & Michelia champaca $\mathrm{L}$ & Fuel, wood, cultural value, & Wood, leaf, root & Increased \\
\hline kera & Musa paradisiaca $\mathrm{L}$ & $\begin{array}{l}\text { Fertilizer, medicine for } \\
\text { diarrhoea and dysentery }\end{array}$ & Leaf extract & Incerased \\
\hline kutki & $\begin{array}{l}\text { Neopicrorhiza scrophulariiflora } \\
\text { (Pennell) D.Y. Hong }\end{array}$ & $\begin{array}{l}\text { Medicine for blood } \\
\text { pressure fever }\end{array}$ & Leaf, Roots & Increased \\
\hline satuwa & Paris polyphylla Smith & $\begin{array}{l}\text { Medicine (root paste ) for } \\
\text { fevers }\end{array}$ & Roots, leaf & Constant \\
\hline sallo & Pinus roxburghii Sargent & Fuel, wood, electricity pole, & Wood, leaf, root & Increased \\
\hline gindari & Premna intergrifolia $\mathrm{L}$ & $\begin{array}{l}\text { Medicine fro Gum problem, } \\
\text { fuel and also use to make } \\
\text { sticks }\end{array}$ & $\begin{array}{l}\text { Bark, leaf and } \\
\text { branches }\end{array}$ & Constant \\
\hline painyu & Prunus cerasoides D.Don & Fuel, fodder, jam & $\begin{array}{l}\text { Leaf, wood, } \\
\text { fruits }\end{array}$ & Increased \\
\hline ambak & Psidium guajava Linn & $\begin{array}{l}\text { Medicine for Diarrhoea, } \\
\text { dysentery }\end{array}$ & Leaf and bark & Constant \\
\hline
\end{tabular}


Y.P. Adhikari and A. Fischer / Our Nature (2010) 8: 122 -130

\begin{tabular}{|c|c|c|c|c|}
\hline ghangaro & $\begin{array}{l}\text { Pyracantha crenulata (D.Don) } \\
\text { Roem }\end{array}$ & Fodder, fuel, & Leaf, wood & Increased \\
\hline falant & Quercus lamilossa & Fodder, control landslides & Leaf, wood & Increased \\
\hline kharsu & Quercus semicarpifolia & Fodder, fuel & Leaf & Constant \\
\hline lali guars & Rhododendron arboretum Smith & $\begin{array}{l}\text { Recreational, fuel, } \\
\text { medicine, }\end{array}$ & $\begin{array}{l}\text { Lower, wood, } \\
\text { leaf }\end{array}$ & Increased \\
\hline aiselu & Rubus ellipticus Smith & Medicine, juice, fruits & Fruits & Increased \\
\hline gogan & Sautauia nepalensis DC. & Fuel, fodder & Wood, leaf & Increased \\
\hline chilaune & Schima wallichii (DC.) Korth. & $\begin{array}{l}\text { Fuel, wood, medicine for } \\
\text { fever, leaf for compost } \\
\text { fertilizer }\end{array}$ & $\begin{array}{l}\text { Wood, bark, } \\
\text { leaf }\end{array}$ & Increased \\
\hline thaune & Taxus bacatta $\mathrm{L}$. & $\begin{array}{l}\text { Poison for fodder, fuel, } \\
\text { stick }\end{array}$ & Leaf & Decreased \\
\hline barro & Terminalia bellirica C.B. Clarke & $\begin{array}{l}\text { Medicine for cough and } \\
\text { bronchitis }\end{array}$ & Seed & constant \\
\hline harro & Terminalia chebula Retz & $\begin{array}{l}\text { Medicine for cough and } \\
\text { bronchitis }\end{array}$ & Seed & constant \\
\hline ban kapas & $\begin{array}{l}\text { Thespesia lampas (Cav.) Dalz.et } \\
\text { Gibs }\end{array}$ & Medicine & Tendril & Increased \\
\hline sisnu & Urtica dioca $\mathrm{L}$. & Vegetable, animals grasses & Leaf & Decreased \\
\hline harchure & Viscum articulum Burm.f. & Medicine & Roots & Increased \\
\hline timur & Zanthoxylum armatum DC. & $\begin{array}{l}\text { Medicine, fuel, wood, } \\
\text { grasses }\end{array}$ & Fruit, leaf & Increased \\
\hline
\end{tabular}

Table 2. Main animal species used in Ghandruk village and status trends.

\begin{tabular}{lllll}
\hline $\begin{array}{l}\text { English name (local } \\
\text { name ) }\end{array}$ & Scientific name & Use for & Part used & $\begin{array}{l}\text { Status trend- } \\
\text { last 2 decades }\end{array}$ \\
\hline $\begin{array}{l}\text { Lrrawaddy squirrel } \\
\text { (lokharke) }\end{array}$ & Callosciurus pygerythrus & $\begin{array}{l}\text { Hunter of mouse } \\
\text { (mouse population } \\
\text { control) }\end{array}$ & ----- & Increased \\
\hline Jackal (syal) & Canis aureus & ------ & ----- & $\begin{array}{l}\text { Increased but } \\
\text { pest }\end{array}$ \\
\hline Wolf (fauro) & Canis lupus & ----- & Increased \\
\hline Serow (thar) & Capricornis sumatraensis & $\begin{array}{l}\text { Meat, shoes, belt, } \\
\text { ornament }\end{array}$ & Body, skin, horns & Increased \\
\hline Monkey (bander) & Cercopithecus hamlyni & ------- & ------ & Increased \\
\hline
\end{tabular}


Y.P. Adhikari and A. Fischer / Our Nature (2010) 8: 122 -130

\begin{tabular}{|c|c|c|c|c|}
\hline $\begin{array}{l}\text { Mongoose (nawori } \\
\text { musa) }\end{array}$ & Herestes edwardsi & $\begin{array}{l}\text { Hunter of mouse } \\
\text { (mouse population } \\
\text { control) }\end{array}$ & ------ & Increased \\
\hline $\begin{array}{l}\text { Porcupine } \\
\text { (dumsi ) }\end{array}$ & Hystrixs brachyura & $\begin{array}{l}\text { Recreation, meat, } \\
\text { medicine of asthma }\end{array}$ & Skin, quills, liver & Increased \\
\hline Rabbit (kharayo) & $\begin{array}{l}\text { Lepus nigricollis } \\
\text { ruficaudatus }\end{array}$ & $\begin{array}{l}\text { Meat, medicine to } \\
\text { stop bleeding, } \\
\text { recreation }\end{array}$ & Fur, skin, teeth & Increased \\
\hline $\begin{array}{l}\text { Monkey (pahare } \\
\text { bander) }\end{array}$ & Macaca assamenis & ------- & ------ & Increased \\
\hline Monkey (rato bander) & Macaca mulatta & ------- & ------ & Increased \\
\hline $\begin{array}{l}\text { Martens } \\
\text { (malchapro) }\end{array}$ & Martes flavigula & ------- & ------ & $\begin{array}{l}\text { Increased but } \\
\text { pest }\end{array}$ \\
\hline Musk deer (kasturi) & Moschus leucogaster & Medicine & 'seductive musk' & Increased \\
\hline $\begin{array}{l}\text { Barking deer } \\
\text { (ratuwa mirga) }\end{array}$ & Muntiacus muntjak & $\begin{array}{l}\text { Recreation, meat, } \\
\text { leather, medicine for } \\
\text { pneumonia }\end{array}$ & $\begin{array}{l}\text { Horns (male), } \\
\text { body, skin, liver }\end{array}$ & Increased \\
\hline Goral & Naemorhedus goral & $\begin{array}{l}\text { Medicine, meat, } \\
\text { recreation, leather }\end{array}$ & Skin, body & Increased \\
\hline $\begin{array}{l}\text { Common Leopard } \\
\text { (chituwa) }\end{array}$ & Panthera pardus & Leather, decoration & Leather, teeth & Increased \\
\hline Tiger (pate bag) & Panthera tigris & Leather, recreation & Skin, teeth & Increased \\
\hline $\begin{array}{l}\text { Monkey (longur } \\
\text { bander) }\end{array}$ & Semnopithecus schistaceus & Medicine for Jaundice & Liver & Increased \\
\hline Black Bear (bhalu) & Ursus thibetanus & $\begin{array}{l}\text { Medicine, food, meat, } \\
\text { recreation }\end{array}$ & $\begin{array}{l}\text { Gall baldder, } \\
\text { teeth }\end{array}$ & Increased \\
\hline
\end{tabular}

were drawn by Bajracharya et al. (2005).

Two animals, Callosciurus pygerythrus and Herestes edwardsi, were found to control mouse populations (Adhikari, 2008). Wild animals were for recreation both hunting and watching, and also meat and leather from wild animal species used for decoration and ornamental purposes. Liver of Muntiacus muntjak, Semnopothecus schistaceus and Hystrixs brachyura is known to cure asthma, jaundice and pneumonia diseases. Similar findings can be drawn from the study of
Tamang (2003). However, Canis aureus and Martes flavigula were found as pest animal for poultry farm and kids of goat in Ghandruk VDC.

Relative preferences of utilisation of tree species as for timber production are Michelia champaca, Alnus nepalensis, Bobbax ceiba, Castanopsis indica, Pinus roxburghii, Schima wallichii. Their timber is of high value, and also branches are used as fuel wood. As a fuel wood tree, Alnus nepalensis and Dendrocalamus hamiltonii are ranked highest in preference. Alnus 
nepalensis, a native species, colonizes landslides and degraded sites very successfully (Jackson, 1994).

Quercus lamelossa (falant) is preferred as a fodder species. It has profuse regeneration in the area. Quercus semicarpifolia (kharsu) is also regarded as an important fodder resource in Ghandruk. Primarily, the species are ranked on the basis of the multiplicity of its utilization. Generally, the species which grow faster and favour the climate of the area are deemed significantly (Adhikari, 2008). One of the examples is Ficus roxburghii (nimaro) that has become increasingly popular as a fodder species in Ghandruk. On the basis of preferential order, the species are selected for plantations. Similarly, Brassiopsis polycantha, Ficus nerifolia, Ficus semicordata and Prunus cerasoides are also significantly used as fooder plants in Ghandruk.

Leaf extract of Ageratum conyzoides and fur of Lepus nigricollis is used to control bleeding from cuts and wounds. Medicinal plants such as Terminalia bellirica, T. chebula, Acorus calamus and Curcuma langa are used to control cough and bronchitis. The leaf and stem extract of Psidium guajava is used as a medicine for diarrhoea and dysentery. Similarly, the leaf extract of Musa paradisiaca, Bauhinia variegate and Bombax ceiba is also used to control diarrhoea and dysentery.

From the study we can conclude that all plants and animals are not over used. Plants and animals are important for people and people are conscious to use them so their status in Ghandruk village is significant, because people have indigenous and tradition knowledge in the utilisation of natural resources for various purposes. But this tradition and indigenous knowledge has been passing on orally from generation to generation without keeping any records. For that reason, it is necessary to keep such traditional and indigenous knowledge of plants and animals with out losing valuable purpose of use forever.

\section{Acknowledgements}

We acknowledge the helps of D.M. Adhikari and S. Adhikari during field sampling. We are grateful and thankful to the residents of Ghandruk VDC and staff members of ACAP office, for their precious time to discuss about trend of plant and animal species with reference to purpose of use. We are indebted to the School of Forest Science and Resource Management of Technische Universität München for granting the travel fare during study period.

\section{References}

ACAP 2008. Progress report of the Annapurna Conservation Area Project 2007-2008. Pokhara, Nepal, ACAP. 45 p.

Adhikari, Y.P. 2008. Sustainable tourism: Boon or dilemma for biodiversity and community development in ACAP area of Nepal. Munich: Sustainable Resource Management, Technische Universität München. 89 p. (M.Sc. Thesis)

Bajracharya, S.B., P.A. Furley and A.C. Newton 2005. Effectiveness of community involvement in delivering conservation benefits to the Annapurna Conservation Area, Nepal. Cambridge University Press. Enviro. Cons. 32(3): 239-247.

Banskota, K. and B. Sharma 1997. Case studies from Ghandruk: Impact of alternative energy technology in reducing pressure on forest resources. Discussion paper Series No. MEI 97/5: ICIMOD.

BCDP 1994. Biodiversity conservation data project. Final report. Kathmandu, Nepal: King Mahendra Trust for Nature Conservation. Hellier, A., A.C. Neton and S.C. Gaona 1999. Use of indigenous knowledge for rapidly 
Y.P. Adhikari and A. Fischer / Our Nature (2010) 8: 122 -130

assessing trends in biodiversity: A case study from Chiapas, Mexico. Biodiver. Cons. 8: 869-889.

Jackson, J.K. 1994. Manual of afforestation in Nepal, vol. I. Revised edition. Forest Research and Survey Centre, Kathmandu, Nepal. pp. 6.

Jackson, W.J. and A.W. Ingles 1995. Developing rural community and conserving the biodiversity of Nepal's forest through community forestry. In Community development and conservation of forest biodiversity through community forestry (Eds. H. Wood, M. McDaniel and K. Warner), Proceedings of a seminar; Oct 26-28, 1994; Bangkok, Thailand: RECOFTC Report 12: 115-135.

Jones, J. 1996. An investigation into the effects on the lives of the women of Ghandruk in Western Nepal by their involvement in the Annapurna Conservation Area project. University of Derby, UK. Third World Development Studies. 56 p. (B.Sc. Thesis)

MOPE 1998. Environmental strategies and policies for industry, forestry and water resource sector. Sector strategies, HMG Nepal. 1: 1925 .

Polunin, O. and A. Stainton 1984. Flowers of the Himalayas. Oxford Universtiy Press. Encyclopedia of Himalayan Medicinal Flora.

Rayamajhi, S. 1994. Management of natural resource: An assessment of the forest conservation program conducted by the Annapurna Conservation Area Project in Ghandruk VDC. Agriculture University of Norway, Norway. 92 p. (M.Sc. Thesis).

Shrestha, A.B., P.W. Cameron, A.M. Paul, E.D. Jack 1999. Maximum temperature trends in the Himalaya and its vicinity: An analysis based on temperature records from Nepal for the period 1971-94. J. Climate 12: 2775-2786.

Shrestha, B.B. and P.K. Jha 2009. Habitat range of two alpine medicinal plants in a TransHimalayan dry valley, central Nepal. $J . M t$. Sci. 6: 66-77.

Shrestha, K. 1998. Dictionary of Nepalese plant names. Mandala Book point, Kantipath, Kathmandu, Nepal. 267 p.

Shrestha, T.K. 1997. Mammals of Nepal. Mandala Book point, Kantipath, Kathmandu, Nepal. $267 \mathrm{p}$.

Tamang, G. 2003. An ethnobiological study of the Tamang people. Our nature 1: 37-41.

Wollenberg, E. 1995. Incomes from the Forest: Methods for the development and conservation of forest products for local communities. International Union for Conservation of Nature and Natural Resources, Center for International Forestry Research. 22 p. 